\title{
Intangible Capital and its Impacts on Economic Growth and Competitiveness
}

\author{
Prof. Dr. Ismail Hussein Ismail \\ Professor in Economics \\ Arab Academy for Science \\ Technology \& Maritime Transport \\ Egypt
Dr. Abeer Mohamed Ali Abd El Khalek
Associate Professor in Economics
Arab Academy for Science
Technology \& Maritime Transport
Egypt

\begin{abstract}
Economic growth and competitiveness of countries are mainly based on intangible resources which can be viewed as a success factor that decides economic performance. So, the purpose of this study is to assess the importance of intangible capital and examine its role in enhancing economic performance measured by both of gross domestic product and global competitiveness index. The empirical analysis revealed that there is a strong relation between countries' economic performance and intangible capital indices. Our study aims to examine this relation based on data from thirty countries which can be classified to developed countries, developing countries and emerging countries.
\end{abstract}

Keywords: Intangible Capital (IC), Intangible Resources, Intangible Assets, Economic Growth, Economic Competitiveness, Global Competitiveness Index (GCI), Gross Domestic Product (GDP), National Intangible Capital (NIC).

\section{Introduction}

Economic growth and Economic competitiveness of any country are determined not only by a high level of natural resources but also by intangible resources including the sphere of information technologies and continuous innovations, and intelligence of a nation given by genetics (Whetzel \& McDaniel, 2006) and Boldov (2010).

According to (Andriessen and Stam, 2005), national intangible capital is "a concept that applies the principles of intellectual capital measurement and management on a macro-economic level in such a way that helps to give direction to future economic developments. intangible capital on national level has recently emerged as a new area of research, where the focus is on understanding and measuring the intangible factors influencing countries' economic performance as a high level of intangible capital reveals a country with knowledge-intensive activities (Edvinsson, 2004), with educated labor force that is better at creating, implementing, and adopting new technologies (Benhabib and Spiegel, 1994), with invisible wealth (Yen-Yun and Edvinsson, 2008) given by nation's competences and capabilities (Malhotra, 2002). All these are, for sure, sources for increasing economic growth rates and global economic competitiveness.

This paper empirically analyses and explores the impact of intangible capital on both of economic growth and economic competitiveness using data on national intangible capital index (NICI), gross domestic product per capita (GDP per capita) and global competitiveness index (GCI) in thirty selected countries. The major proposition for which the study was examined included that there is a significant correlation between GDP per capita and NIC, and also between GCI and NIC which means that the good use of-and benefiting from- country's intangible capital affects its economic performance positively. So, governments must better manage the intangible resources that increasingly determine the success of their economies. 


\section{Literature Review}

Development potential of countries and regions is mainly based on intangible resources and hidden capabilities. It seems that a key issue is to reveal the key success factors creating the value for nations and determining its competitive advantage (Marcina, 2013).

Resources that are valuable, rare, and impossible to copy or replace are the source of long-lasting competitive advantage (Kozak M., 2007). This regards both knowledge-based corporations and geographical areas, which build their competitive advantage on the implementation of national and regional innovation systems (Kozak M., 2011).

Countries rich in intangible assets fare better in terms of national wealth than those whose assets are limited to land, tools, and labour (Malhotra, 2003; World Bank, 1998). In today's economy, the main sources of development are not materials and labour but mainly the capability to create and utilize knowledge resources (Bounfour A., Edvinsson L., 2005). It has been proved beyond doubt that knowledge-based assets play a major role in the value creation process. Investments in intangible assets are viewed as the most important sources of performance.

The Solow residual (Solow, 1956) considers that long term growth depends exogenously on technological progress and population growth. Another strand of literature has focused entirely on investment in $\mathrm{R} \& \mathrm{D}$, human capital, knowledge spillovers and their impact on growth. As a result, a debate has arisen regarding endogenous and exogenous growth, with different interpretations insofar as how to reach the stationary state. In this sense, Romer (1986) and Lucas (1988) determine that capital investment and the accumulation of knowledge or human capital are a source of endogenous growth, both indicating that growth diverges.

Recent studies proved that intellectual capital can contribute greatly to the improvement of the economic competitiveness and living standards which- in turn- due to enhancement of economic performance. According to (Marr, 2004), economic and social development of a modern nation is dependent on the intellectual capital and human capital at a rate concurrent with that of other forms of capital (physical, financial, etc.).The competitiveness of countries in attracting foreign investors is more often determined by their specific and unique intangible resources. Intangible investments in research and development and innovation are viewed as the most important sources of performance (Marcina, 2013). IC is one of the main production factors in today's economic environment. In the knowledge economy, the value of countries, regions, organisations and individuals is directly related to their knowledge and intellectual capital (Edvinsson L., Bounfour A., 2004).

(Bontis N., 2004) argues that the expectations from finding reliable measures of knowledge assets at a national level is that such measures can help governments better manage the intangible resources that increasingly determine the success of their economies. Sahin et al. (2006), Kao et al. (2008) and Cho et al.(2008) define competitiveness as the ability to create welfare, the relative ability of a nation to create and maintain an environment in which enterprises can compete so that the level of prosperity can be improved and suggest also that each comprehensive assessment of competitiveness should contain an outcome evaluation and a process evaluation, on one hand, and must be compared to other nations of similar economic development, on the other hand. According to Krugman (1996) the concept of competitiveness is "elusive or meaningless when applied to national economies; for economies with little international trade, competitiveness is a specifically maintained to be a funny way of saying productivity. Another author considers that international competitiveness is said to occur whenever the economic welfare of a nation is advanced through an increase in the flow of trade or through an alteration in the conditions of trade starting from a presumed initial equilibrium (Coldwell 2000).

Garelli (2006) captured two very different definitions for the concept of competitiveness: on one hand, he says that competitiveness analyses how nations and enterprises manage the totality of their competencies to achieve prosperity or profit; on the other hand, he defines the competitiveness of nations to be a field of economic theory, which analyses the facts and policies that shape the ability of a nation to create and maintain an environment that sustains more value creation for its enterprises and more prosperity for its people. The issue of national competitiveness is a matter of considerable importance to both managers and public policy makers alike (Thompson, 2004). 


\section{Methodology}

This empirical study assesses the important impacts of intangible capital on economic growth and countries' competitiveness in the selected countries.

Therefore, an analytical approach has been employed using data regarding both of National Intangible Capital Index (NICI), Global Competitiveness Index (GCI) and Gross Domestic Product per capita (GDP per capita) for 30 countries are classified as developed, developing and emerging countries. Data on NIC, GC and GDP were collected from global competitiveness report 2016-2017.

NIC was measured by the ELSS (Edvinsson-Lin-Ståhle-Ståhle) methodology for measuring stock of national intangible capital and its economic impacts. NIC index values as a measure for stock of country NIC potentials embedded in its national intangible capital. National Intangible Capital (NIC) consists of four basic dimensions according to the model by Edvinsson \&Malone (1997) which consists of 48 different indicators representing the four main NIC categories: human capital (capacity and capability of a country population), market capital (global business attractivity of country), process capital (operational functionality of the nation) and renewal capital (capacity for knowledge creation, exploitation and innovation).The data will be used to assess the contribution of NIC in GDP formation as percentage of GDP, i.e. how much of GDP is depending on and produced by utilizing NIC. Also, the data will be used to examine the correlation between NIC and GCI. For the analytical study purposes, it is hypothesized that the greater the countries' NIC, the higher both of GDP per capita and GCI of that country. So, the study will examine the next two hypothesizes:

Hypothesis 1: There is a significant positive relationship between NICI and GDP per capita. Hypothesis 2: There is a significant positive relationship between NICI and GCI.

The empirical study depended on a combination of inductive and deductive approach by using the collected data and analyzing how can the improvement of NIC utilization strategies contribute to increase growth rates and enhance the global competitiveness situation of the country. The inductive approach has been employed to process the broad data that can represent the part of our interest. The deductive approach further helps in determining if more data or themes are required from the previous set for the evaluation of the established set. In such manner, the mechanisms of increasing the role of intangible capital in enhancing economic performance have been developed to provide a basis for the improvement of economic performance strategy and policy.

\section{Data analysis and Discussion}

Data related to the three main variables in our study: national intangible capital (NIC), gross domestic product per capita (GDP per capita) and global competitiveness index (GCI) for 30 countries are shown in table 1. We use as sources to identify the level of the three variables: World Economic Forum, the Global Competitiveness Report 2016-2017. 
Table 1:NICI, GDP per capita, GDP impact and GCI for 30 countries.

\begin{tabular}{|c|l|c|c|c|c|}
\hline Rank for NICI & Country & NICI & $\begin{array}{c}\text { GDP Per } \\
\text { capita }\end{array}$ & $\begin{array}{c}\text { GDP Impact } \\
(90)\end{array}$ & GCI \\
\hline 1 & USA & 8.98 & 55805.2 & 73.80 & 5.7 \\
2 & Singapore & 8.93 & 52887.8 & 53.23 & 5.7 \\
3 & Sweden & 8.55 & 49866.3 & 75.74 & 5.5 \\
4 & Denmark & 8.34 & 52114.2 & 68.82 & 5.3 \\
5 & Switzerland & 8.24 & 80675.3 & 63.23 & 5.8 \\
6 & Finland & 8.18 & 41974.0 & 69.43 & 5.4 \\
7 & Luxembourg & 7.99 & 101994.1 & 61.68 & 5.2 \\
8 & Canada & 7.83 & 43332.0 & 57.79 & 5.3 \\
9 & Japan & 7.82 & 32485.5 & 44.29 & 5.5 \\
10 & Lithuania & 7.80 & 14210.3 & 56.57 & 4.6 \\
11 & Netherlands & 7.75 & 43603.1 & 62.00 & 5.6 \\
12 & Norway & 7.66 & 74822.1 & 52.58 & 5.4 \\
13 & Israel & 7.60 & 35343.3 & 64.72 & 5.2 \\
14 & HongKong & 7.58 & 42389.6 & 62.74 & 5.5 \\
15 & Germany & 7.57 & 40996.5 & 61.36 & 5.6 \\
16 & Iceland & 7.44 & 50854.6 & 58.48 & 5.0 \\
17 & United Kingdom & 7.38 & 43770.7 & 64.27 & 5.5 \\
18 & Australia & 7.38 & 50961.9 & 59.05 & 5.2 \\
19 & Taiwan & 7.36 & 22287.6 & 60.80 & 5.3 \\
20 & Beloium & 7.35 & 40106.6 & 63.20 & 5.3 \\
21 & Qatar & 7.31 & 76576.1 & 62.15 & 5.2 \\
22 & Austria & 7.13 & 43724.0 & 53.03 & 5.2 \\
23 & France & 7.12 & 37675.0 & 49.66 & 5.2 \\
24 & Ireland & 6.97 & 51350.7 & 56.26 & 5.2 \\
25 & Korea & 6.94 & 27195.2 & 52.59 & 5.0 \\
26 & New Zealand & 6.91 & 37044.9 & 50.41 & 5.3 \\
27 & UAE & 6.70 & 36060.0 & 49.41 & 5.3 \\
28 & Estonia & 6.12 & 17288.1 & 44.86 & 4.8 \\
29 & Slovenia & 6.11 & 20732.5 & 43.19 & 4.4 \\
30 & Spain & 5.94 & 25864.7 & 40.26 & 4.7 \\
\hline
\end{tabular}

(Source): World Economic Forum, Global Competitiveness Report 2016-2017.

Table2: Correlation between NICI , GDP per capita and GCI.

\begin{tabular}{|c|c|c|c|c|c|}
\hline & $\mathrm{NICI}$ & & GDP per capita & GCI & \\
\hline Mean & 7.499333 & & 44799.73 & 5.263333 & \\
\hline \multirow[t]{2}{*}{ SIDEV } & 0.129801 & & 3623.067 & 0.059269 & \\
\hline & & $\mathrm{N}$ & Pearson & $R^{2}$ & $\mathrm{P}$ \\
\hline \multirow{2}{*}{\multicolumn{2}{|c|}{$\begin{array}{l}\text { NIC and GDP per capita } \\
\text { NIC and GCI }\end{array}$}} & 30 & 0.8656 & 0.7494 & $<0.001$ \\
\hline & & 30 & 0.8823 & 0.7792 & $<0.001$ \\
\hline
\end{tabular}

(Source): Table1 and own calculation

$$
\mathrm{N} \text { - Number of observation } \quad \mathrm{P} \text { - Level of significance }
$$

Based on combining data of national tangible capital, gross domestic product and global competitiveness index of the thirty selected countries, it has shown the following:

1. The Pearson index estimated to distinguish the correlation between NICI and GDP per capita is 0.8656 with a strong and direct correlation that shows that the countries with better score for NICI are more developed and have a higher level of GDP per capita. 
2. The level of $\mathrm{R}^{2}$ for the relation between NICI and GDP per capita is 0.7494 which reflect a significance of the correlation of 0.001 .

3. It can be observed a direct and very strong correlation (Pearson $=0.8823$ ) between NICI and GCI which means that in the countries where the value of NICI is high the competitiveness is high. This fact is emphasized also by the value of $\mathrm{R}^{2}$ that is 0.7792 .

\section{Conclusion}

This paper examined the relation between economic growth, economic competitiveness and intangible capital for thirty developed, developing and emerging countries using data on the three main variables: GDP, GCI and NICI. By this paper we identified a strong positive relation between gross domestic product per capita and national intangible capital index, and also a strong positive relation between global competitiveness index and national intangible capital index.

According to Pearson $\mathrm{R}$ and $\mathrm{R}^{2}$ results, these relations demonstrate that intangible capital is important source for enhancing economic performance based on data from the selected thirty developed, developing and emerging countries as the results obtained for Pearson and $\mathrm{R}^{2}$ demonstrate that there is a strong and direct correlation between national intangible capital and both of gross domestic product and national competitiveness with significance of the model of 0.001. The Nordic European Countries, United States, Canada, Australia and Switzerland are countries with very high level of economic growth based on the high GDP per capita, high competitiveness and national intangible capital. The other developed European Countries (Germany, Austria, France, United Kingdom, Iceland, Ireland, and France), and Japan are countries with high competitiveness, high level of GDP per capita but with a medium level of national intellectual intangible capital. Taiwan is in the second group because of its high level of competitiveness, not because of the level of GDP per capita that is lower middle. The emerging countries like China and Korea have lower middle level of GDP per capita, national competitiveness and national intangible capital. In conclusion, for achieving and maintaining high rates of economic growth and competitiveness, a country must improve its national intangible capital index as our findings showed that national intangible capital is a key source for economic growth and national competitiveness. So, managing and best allocation of this capital must represent one of the most important objectives of a nation's policy makers.

\section{Limitations \& direction for future studies:}

To successfully maximize the intangible capital contribution to countries' economic performance and growth, official policy must operate at two levels: the first level is exploring and developing the available intangible resources, and the second is enhancing the best allocation of these resources. So, future studies are needed to design an integrated plan helping the country to explore, develop and allocate its intangible capital components, especially the countries which are poorer in their tangible resources. The future studies may also have to modeling the process of maximizing the economic returns of countries' intangible capital.

\section{References}

Alkire, S. and Santos, M.E. (2010) Multidimensional Poverty Index, Oxford Poverty \& Human Development Initiative, Oxford.

Amartya Sen, Development as Freedom. (1999), Oxford University Press. Boldov O.N, The correlation between economic growth and national wealth- dynamics with accounting for intangible capital, Studies on Russian Economic Development, 21(2): 124-131, 2010.

Benhabib, Jess, and Mark Spiegel, The role of Human Capital in Economic Development, Evidence from aggregate cross-country data, Journal of Monetary Economics, 34: 143-173, 1994.

Benjamin M. Kozak, Melissa Y. Tjota, Kelly L. Close (2011). Journal of Diabetes Volume 3, Issue 1.

Bounfour A., Edvinsson L. (2005), Intellectual Capital for Communities, Nations, Regions, and Cities, Elsevier Butterworth-Heinemann, Oxford, London.

Bernard Marr (2004), Measuring and benchmarking intellectual capital, Cranfield School of Management, Cranfield, UK.

Bontis N. (2004), National Intellectual Capital Index, A United Nations initiative for the Arab region, Journal of Intellectual Capital, Vol. 5 (1). 
Clark A. Chinn, Betina A. Malhotra, Epistemologically Authentic Inquiry in Schools: A Theoretical Framework for Evaluating Inquiry Tasks Department of Educational Psychology, Rutgers, The State University of New Jersey, New Brunswick,

Deborah L. Whetzel \& Michael A. McDanie, Prediction of National Wealth, Intelligence 34, 449-458, 2006.

Edvinsson, L., and M.S. Malone (1997), Intellectual Capital, Piatkus, London.

Edvinsson Leif, the Intellectual Capital of Nations, Handbook on Knowledge Management, Vol. 1, 2004.

Edvinsson L., A. BounfourAssessing (2004), National and Regional Value Creation, Measuring Business Excellence, Vol. 8, Issue 1.

Garelli S. (2006), Competitiveness of Nations: The Fundamentals, in IMD World Competitiveness Yearbook.

Kozak M. (2007), Dynamic Intellectual Capital in System Approach to Regional Development, International Journal of Learning and Intellectual Capital, 8 (1).

Kozak M. (2013), Intellectual Capital as a Key Factor of Socio-Economic Development of Regions and Countries, Procedia Economics and Finance, Volume 6.

Mark P. A. Thompson (2004), Placing Knowledge Management in Context, Judge Institute of Management, University of Cambridge.

Paul M. Romer (1986), Increasing Returns and Long-Run Growth, the Journal of Political Economy, The University of Chicago Press, Volume 94, Number 5.

Paul Krugman (1996), Making Sense of the Competitiveness Debate, Oxford Review of Economic Policy, Oxford University Press, Vol. 12(3).

Robert E. Lucas (1988), On the mechanics of economic development, Journal of Monetary Economics, Volume 22, Issue 1.

Robert M. Solow (1956), A Contribution to the Theory of Economic Growth,The Quarterly Journal of Economics, Vol. 70, No. 1

Yen-Yun, Lin, Carol, and Leif Edvinsson, National intellectual capital: comparison of the Nordic countries. Journal of Intellectual Capital, 9(4): 525-545, 2008. NJ 08901, USA, Malhotra, 2002.

Yogesh Malhotra (2003), Measuring Knowledge Assets of a Nation: Knowledge Systems for Development, School of Management Syracuse University, Syracuse, NY 13244-2130. World Economic Forum, Global Competitiveness Report 2016-2017. 